more than even the heavy instruments weigh. The motion of the kite was quiet and uniform, only a slight tacking indicating *a change of wind. At a height varying from $190 \mathrm{ft}$. to 330 ft. the only effect of a change in the preasure of the wind was to cause a moderate ascension when the force of the wind increased, and a slow descent when the wind pressure decreased. 't he use of a tail or landing line, such as is

\section{Some Kite Records in the United States.}

(By William A. Eddy, Bayonne, N.J)

I have so far taken about 400 kite photographs, nearly all of which are perspective riews. On July 28th, 1898, General A. W.

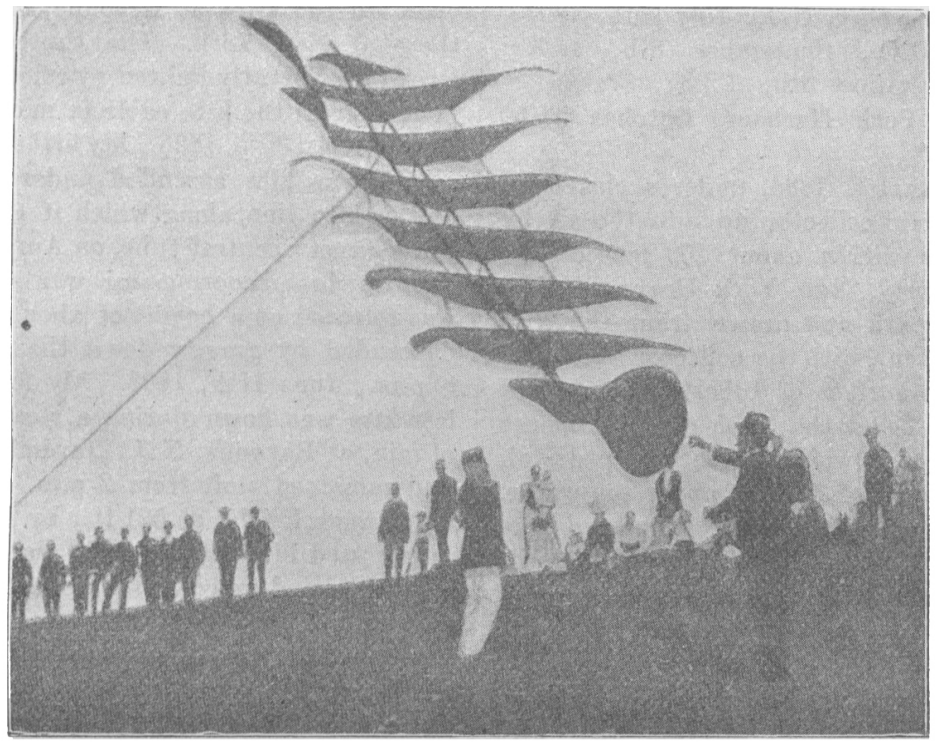

[From the English Mechanic.

generaliy attached to a balloon, proved mest satisfactory. The line was $33 \mathrm{ft}$. long, and hung from the neck of the rudder. The experiment of securing a dynamite cartridge to the landing
Greely authorised me to send 26 of my kites and other apparatus to Porto Rico, by way of Newport News, Va. They arrived about two rays before the declaration of peace. It was

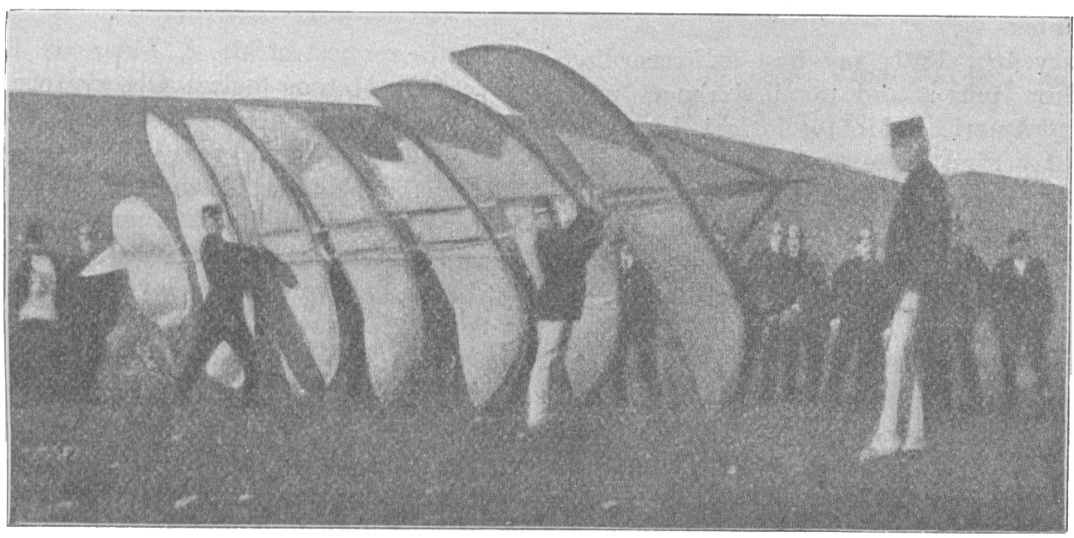

[From the English Mechanic.

line and exploding it at a considerable height was tried, and the result showed that the kite could, if desired, be used for the purpose of producing rain by explosions. intended to photograjh the enemy's fortifications. I have not yet received a report from Porto Rico. Following are dates of iny first mid-air photographs from kites in different 
localities for purposes of scientific record:Bayonne, N.J. May 30th, 1895; Blue Hill Oibservatory, August 20th, 1895; New York, September 25th, 1895; Portland, Me., August 19th, 1896; Boston, Mass., August 25 th, 1896; Elmont; L.I., September 7th, 1896; Philadelphia, Pa., May 15th, 1897 ; simultaneous mid-air photographs from two cameras at Now York, June 5th, 1897 ; State Camp, Peekskill, N.Y., June 20th, 1897, State Camp, Sea Girt, N.J., July 25th, 1897 ; Washington, D.C., September 8th, 1897; Reading, Pa., June 8th, 1898; Statue of I.iberty, New York Harbour, October 27th, 1898.

On November 1st, 1898, under a elear sky, I sent an electric collector up into the air by means of kites within about 100 feet of the Statue of Liberty, New York Harbour. The first oleetric spark was drawn from the lite wire at 11.15 a.m., with the collector about 200 feet above the surface of Liberty Island, and about 100 feet below the torch of the immense statue of bronze, which, with its pedestal, reaches to $a$ height of 328 feet above the water. I.ater, when I carried the kite supported wrre within about $30 \mathrm{ft}$. of the statue, an immense mass of bronze, the electric action reased. Other experiments on November 1st, 3rd and 4th proved that the statue did not appreciably affect the air beyond a distance of 100 feet from its surface. Upon carrying the wire within $70 \mathrm{ft}$. of the statue, the electric action in the wire almost ceased. I hope to more closely define this electric influence later by triangulating distances and timing the spark frequency as related to the distance between the terminals.

Following is a list of my miscellaneous kite experiments :-

February 4th, 1891, my first self-recording tomperature taken, and detailed report published in "American Meteorological Journal," July, 1891. First meteorograph in the world lifted by means of kites, at Blue Hill Observatory, 10 miles south of Boston, Mass., August 4th, 1894 ; first kite telephone message, with kite wire extending over houses and trees, successfully carried out by the writer on Denember 5th, 1896; first aerial camera obscura, which I named the vista-scope, ascended to a height of about $300 \mathrm{ft}$., suspended from the kite cable, on August 15th, 1897, at Bayonne, N.J., and the sails of moving yachts and the roofs and sides of distant houses were visible to those lying in the grass and looking upward with a powerful field glass into the dark cavity of the camera obscura. On November 12th, 1897, my first cross-bow aero- plane was shot from the kite cable aloft, landing more than $1,000 \mathrm{ft}$. away. It was fired at night, but sparks of saltpetre fuse were : ttached to the arrow-head, and traced it in the darkness. My first self-illumined single plane kite ascended March 26th, 1898, with the lighted lantern within 6 in. of the surface of the kite. My first sinultaneous kite temperature was taken at New York and Bayonne, N.J., April 9th, 1898. Mr. Henry L. Allen operated the kites at Bayonne, and I operated those at Now York. 'The I'nited States lag was first brilliantly lighted by coloured fire, suspended from the kite cable in mid-air near the flag on April 30th, 1898. My first dynamite messenger war kite ascended under wind pressuro up the kite line, along which it glided upward by means of a central tribe, on April 2nd, 1898; and $\mathrm{my}$ first shooting-star war signal lantern was released at a height of about $900 \mathrm{ft}$., and descended by gravity down the kite cable at 8 p.m., June 17th, 1898. My first cloth tailless kite was flown during a steady downpour of rain, at Bayonne, N.J., November 4th, 1893, and remained aloft from 2 p.m. to 5 p.m., th an average height of $591 \mathrm{ft}$., by triangulation. I first used kites of a specific diameter to measure the wind relocity by means of the variation in pull at the earth, as compared with anemometer records, which established the law of this pull, as related to wind velocity, on December 18th, 1897, a full account of which appeared in the "New York Herald," with au illustration, on Monday, December 20th, 1897.

\section{Lamson's New Kite.}

At the request of Mr. A. Lawrence Rotrh, of Blue Hill Meteorological Observatory, I. send you photographs of the kite which I designed and made for him a year or more ago. The kite has, we believe, flown to the highest point so far attained by kites. August 26th, 1898, it reached $11,495 \mathrm{ft}$. above its starting point, or 12,124 ft. above the sea level. Two or three smaller Hargrave kites were attached to the main line a mile or more below the leader, to assist in lifting the wire. The previous best llight was on October 15th, 1897, when it reached $11,847 \mathrm{ft}$. above the sea level.

The dimensions of the kite are as follows: Width or spread of wings, $11 \mathrm{ft} .2$ in.; total length, $11 \mathrm{ft} .8 \mathrm{in}$; width of front supporting surfaces "fore and aft," average $2 \mathrm{ft}$. $9 \mathrm{in}$.; height between upper and lower surfaces, $2 \mathrm{ft}$. 7 in.; space between front and rear surfaces, 